\begin{tabular}{|c|l|}
\hline Title & Laboratory experiments on spatial use and aggression in three sympatric species of shrew in Hokkaido, Japan \\
\hline Author(s) & Ohdachi, Satoshi \\
\hline Citation & $\begin{array}{l}\text { Mammal Study, 22(1-2), 11-26 } \\
\text { https://doi.org/10.3106/mammal study.22.11 }\end{array}$ \\
\hline Issue Date & 1997 \\
\hline Doc URL & http://hdl.handle.net/2115/44404 \\
\hline Type & article \\
\hline File Information & MS22-1-2_11-26.pdf \\
\hline
\end{tabular}

Instructions for use 


\title{
Laboratory experiments on spatial use and aggression in three sympatric species of shrew in Hokkaido, Japan
}

\author{
Satoshi OHDACHI \\ Institute of Low Temperature Science, Hokkaido University, Sapporo 060, Japan \\ Fax. +81-11-706-7142, e-mail. ohdachi@bio. hokudai. ac. jp
}

\begin{abstract}
Aggression and the use of vertical and horizontal space in the presence of con- or hetero-specific individuals were investigated in laboratory for Sorex unguiculatus, S. caecutiens, and S. gracillimus in Hokkaido, Japan. S. unguiculatus frequently used the below floor strata of experimental cages or subterranean burrows as their main area of activity, whereas $S$. caecutiens and $S$. gracillimus mainly used the cage floor or the ground surface. The presence of con- or hetero-specific individuals led to no changes in any of the three species in the use of space, or in behavioral patterns (active/inactive; underground/resting/ moving on the ground surface). When two individual shrews were introduced into two interconnected cages, they tended to remain in separate cages, with the exception of S. gracillimus with a conspecific. Dominance rank was highest in $S$. unguiculatus, intermediate in S. caecutiens, and lowest in S. gracillimus. S. caecutiens attacked $S$. gracillimus most frequently and $S$. gracillimus received attacks from $S$. caecutiens most frequently. The implication of this research is that severe interference competition may occur in the field between $S$. caecutiens and $S$. gracillimus.
\end{abstract}

Key words : coexistence, interference competition, niche shift, surface activity, underground activity.

Sorex unguiculatus, S. caecutiens, and S. gracillimus are three common species of shrew occurring throughout Hokkaido. When S. caecutiens and S. gracillimus occur together, they are never the two most abundant species (Ohdachi and Maekawa 1990a, Ohdachi 1995a). Ohdachi (1995b) confirmed that $S$. caecutiens and S. gracillimus share a greater similarity in their diets than do either of these species and $S$. unguiculatus. These findings indicate that interspecific competition is likely to be more severe between $S$. caecutiens and $S$. gracillimus. Further, $S$. unguiculatus is a much stronger burrower than either of the other two species (Ohdachi 1995c). It is suspected, therefore, that severe interference for space exists between $S$. caecutiens and S. gracillimus.

There is the potential for a niche shift by one species, when in the presence of the other, that could influence the outcome of competition. If both species exhibit interference competition, but neither of them changes any of its niche 
dimensions, then the physically superior individual or species may exclude the inferior individual or species from good habitat or a good position (e.g., Hardin 1960, Schoener 1975, Werner and Hall 1976, Holbrook 1979, Parker and Sutherland 1986, Alatalo and Moreno 1987, Arthur 1987). In such cases, aggressive behavior and physical superiority are essential keys for guild formation, and thus make it interesting to investigate whether individuals change their use of space (or niche) in the presence of other individuals.

For cryptic species whose life histories are poorly known, such as the shrews of Hokkaido, it is difficult to carry out extensive field studies of space use and interactions. Ohdachi (1992) described the home ranges of sympatric shrews in Hokkaido, but was only able to present limited information about interspecific interactions because of the difficulties in observing them directly. Therefore, the alternative means of investigating direct interactions in the laboratory was chosen for this study. Although the reality of simulated situations, particularly in the scaling of time and space, is questionable (Bennett 1990), the results obtained from laboratory experiments can, nevertheless, complement those from field studies (Diamond 1986, Hairston 1989, Keddy 1989).

This paper serves to describe: (1) interspecific differences in the use of space, (2) interspecific interactions such as aggressive behavior, and (3) the impact of the presence of another individual on the use of activity space and on behavioral patterns, in S. unguiculatus, S. caecutiens, and S. gracillimus in Hokkaido. For these purposes, two different laboratory experiments were conducted.

\section{MATERIALS AND METHODS}

\section{Experiment 1}

The first experiment was designed mainly to examine the effects of the presence of con- or hetero-specific individuals on vertical space use. Animals used in this experiment were nine $S$. unguiculatus (5 young males, 4 young females), eight $S$. caecutiens (1 adult male, 4 young males, 3 young females), and five $S$. gracillimus (3 young males, 2 young females), which were captured in Yufutsu Moor (Tomakomai-shi) during 14-18 June 1992 and in a wind-shelter belt near the Teshio Experimental Forest of Hokkaido University (Horonobecho) during 25 June to 27 August 1992. Basically, sexually immature individuals were used in experiments in order to lessen the potential effect of sexual behavior on space use. Shrews were kept under a 16-hr light and 8-hr dark photoperiodic cycle at $20 \pm 2^{\circ} \mathrm{C}$. The light intensity was maintained at 1420 lux during the light period and at 12 lux during the dark period (as measured at the center of laboratory floor; See Ohdachi 1994, 1995c for details). Each experiment was conducted throughout the 8-hr dark period, from 11 October 1992 to 6 January 1993.

Each observation cage contained 20 levels and the floor surface, and was fitted with two staircases (Fig. 1). Each of the boards separating the levels 


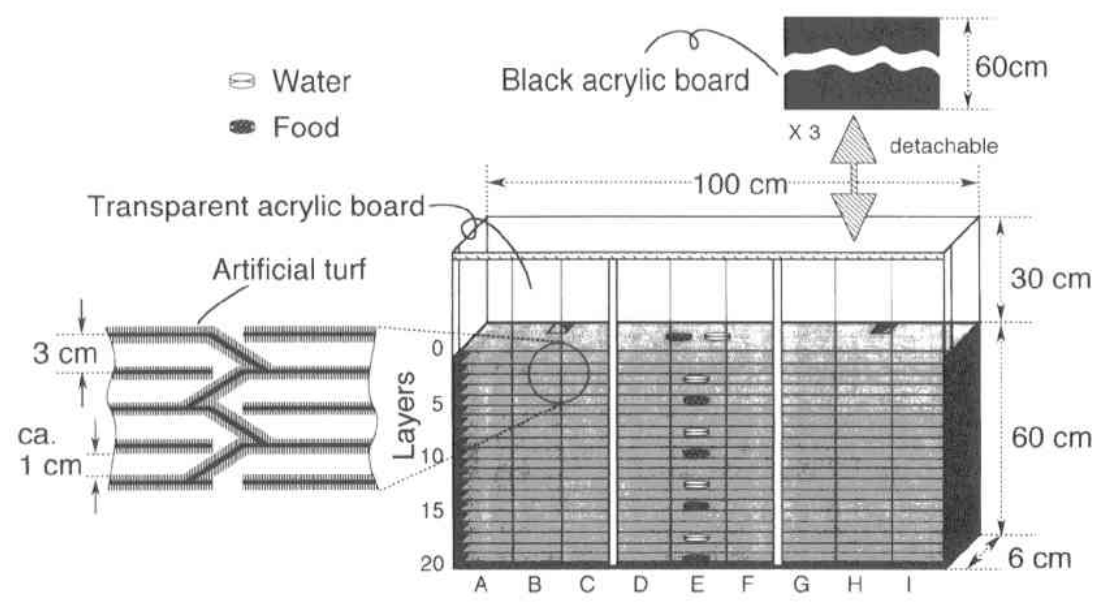

Fig. 1. The experimental device for Experiment 1. Black boards were removed just before an experimental session.

was covered on both sides with artificial turf so that shrews were always in physical contact with this surface while moving about between levels. Pieces of tissue paper, which simulated ground litter, were located on the cage floor. Trays of the mixed paste diet and water were located as shown in Fig. 1. Black acrylic boards were attached in front of transparent cage walls, so as to exclude light before observation periods.

Either one or two animals were released simultaneously onto the cage floor thirty minutes before the onset of the dark period. The black masking boards were gently removed immediately after the light was turned off. The location and behavior of each shrew were then recorded every fifteen minutes using a weak red spot-light. After finishing an experimental session, the animals were removed and the cages were washed with ethanol and kitchen detergent and then dried out.

The vertical location of a shrew was assigned to one of five categories: surface level (0), levels 1-5, 6-10, 11-15, and 16-20. Utilization of each level by an individual was obtained by averaging the percent frequencies for the level among several experimental sessions under the same experimental treatment. Seventy experimental sessions were used for analysis.

The dominance relationship between two individuals was defined as follows: the "loser" was the individual which avoided, escaped, or fled from its "opponent" when two animals encountered or fought, while the opponent under these circumstances was a "winner". If the number of wins and losses observed were the same, the two animals were judged to be "even". When no direct contact was observed, this was defined as "no match".

\section{Experiment 2}

The second experiment was designed to investigate aggressive behavior 
and the effect of the presence of con- or hetero-specific individuals on the use of space use (especially horizontal use) and behavioral patterns. Animals used in this experiment included ten $S$. unguiculatus ( 1 adult female, 5 young males, 4 young females), three $S$. caecutiens (2 young male and 1 young female), and five $S$. gracillimus (2 adult females, 1 young male, and 2 young females), which were captured in wind-shelter belts near the Teshio Experimental Forest of Hokkaido University during 6-22 August 1993, and one adult female $S$. caecutiens that was captured in Yufutsu Moor in July 1992. Laboratory conditions were the same as in Experiment 1. Each experiment was conducted throughout the dark period, from 30 August to 24 November 1993.

Two animals were released separately into experimental cages (Fig. 2) one day before an experiment, with both sides of the connecting tube being closed by rubber plugs. The rubber plugs were removed five minutes before the onset of the dark period. As a control experiment, an empty cage was connected to a cage where a single shrew was introduced. The first cage into which a shrew was introduced, prior to the cages being connected for the experiment, is hereafter referred to as the "home" cage, while the other is referred to as the "away" cage.

Shrew behavior was recorded using a video camera recorder (in the twilight vision mode) throughout the dark period, and sampled every 5 minutes while replaying the video tapes. Behavior was ascribed to one of three categories: "underground activity" (shrews were underground or digging), "in

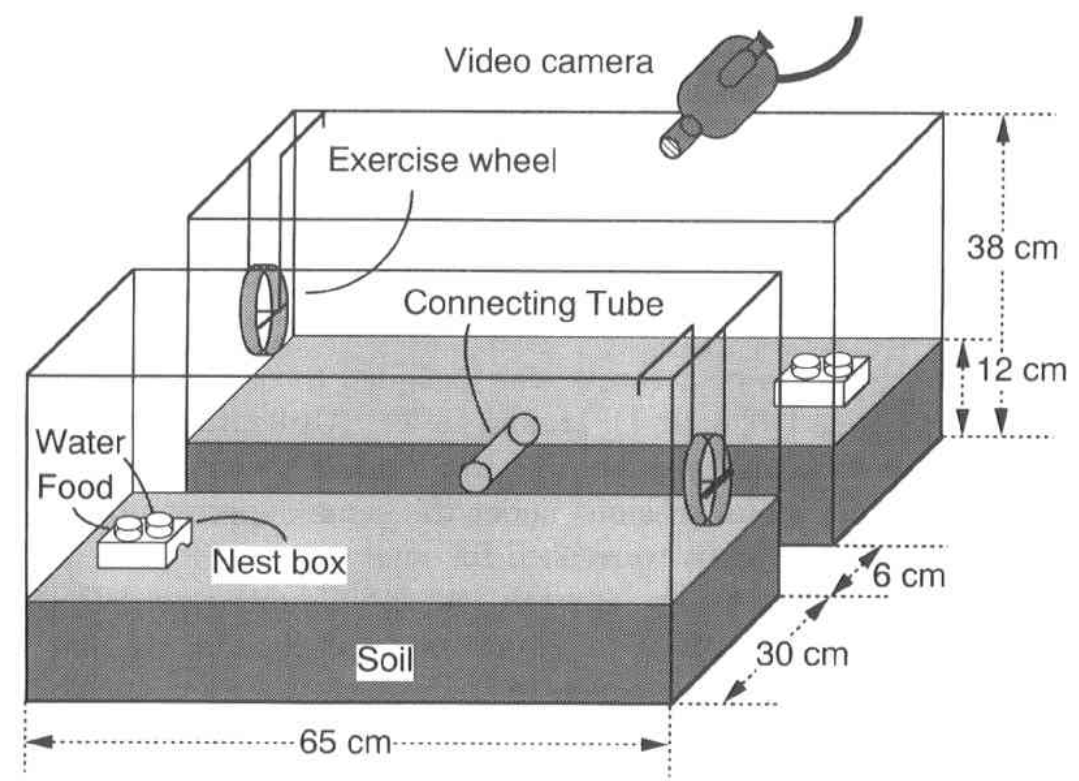

Fig. 2. The experimental device for Experiment 2. A connecting tube is plugged until an experimental session is started. Note that the bottom of a nest box was open to the ground surface. 
action on the ground" (shrews were in nest boxes or resting on the ground surface), and "moving on the ground" (shrews were walking or running on the ground surface, or whirling exercise wheels). Other behaviors, such as eating, drinking, or self-grooming, were usually too brief to be recorded by the 5 minute-interval sampling method. Behavior below ground and in nest boxes could not be observed in this experiment. Because S. unguiculatus usually constructed burrows in its "home" cage and some entrances of the burrows opened under its nest box, it was impossible to distinguish "underground activity" and "inaction on the ground" when it was in its nest box. According to preliminary observations, however, S. unguiculatus usually entered burrows under its nest box instead of staying on the ground surface when in its nest box. Therefore, unless it was possible to verify that the shrew did not enter a burrow, the case in which $S$. unguiculatus was in a nest box was classified as "underground activity". Preliminary observations revealed that S. caecutiens and $S$. gracillimus usually stayed on the ground surface under the nest box of $S$. unguiculatus, and that they were usually inactive there. Thus, when $S$. caecutiens or S. gracillimus was in the "away" nest box of S. unguiculatus, this was classified as "inaction on the ground", except when they obviously entered burrows under the nest box.

The frequency of each behavioral category for an individual was obtained by averaging the observation frequencies of the category across several experimental sessions under the same experimental treatment. Sixty-two experimental sessions (496-hour observation in total) were used for the analysis.

The number of attacks and the dominance relationship between individuals were determined by continuous scanning of the video tape throughout the 8 -hr experimental session (complete observation). Attacking behavior includes chasing, biting body or tail, and wrestling. Attacks interrupted for more than 10 seconds was counted separately. The criteria for "win", "lose", and "no match" were the same as in Experiment 1. In this experiment, however, "even" was defined as follows: frequent counterattacks were observed or an individual did not escape from the opponent even when it was attacked often.

\section{RESULTS}

\section{Experiment 1}

Sorex unguiculatus was more subterrestrial than either $S$. caecutiens or $S$. gracillimus. S. caecutiens used the surface level significantly more frequently than $S$. unguiculatus during its active phase (ANOVA with arcsine transformation by Scheffe's method, $\alpha=0.05$ ), but utilization of the other levels did not differ significantly between these two species (Fig. 3). S. gracillimus appeared to frequently use the surface level as did S. caecutiens, although its surface activity was not statistically different from that of either S. unguiculatus or $S$. caecutiens (Fig. 3).

Vertical space use did not differ significantly between the experimental treatments in each of the three species (Fig. 3). The dominance relation also 
A. S. unguiculatus
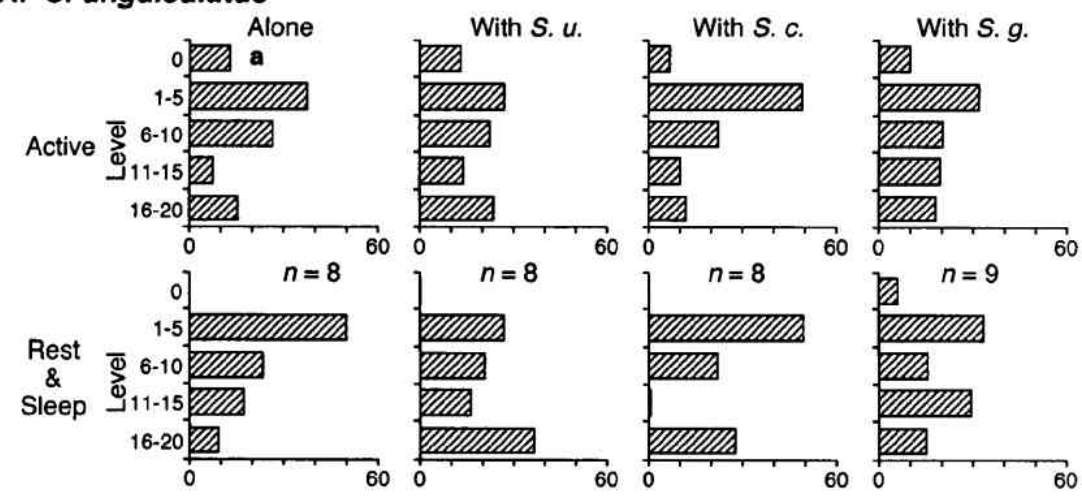

\section{B. S. caeutiens}
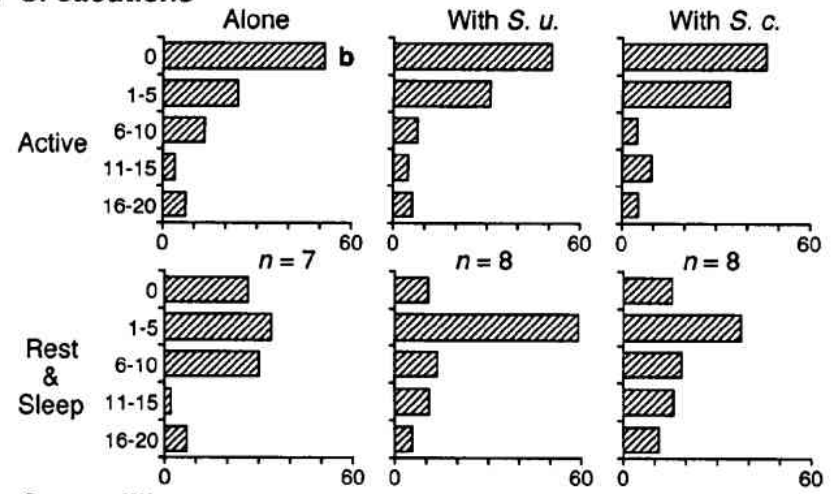

With S. $g$.

C. S. gracillimus
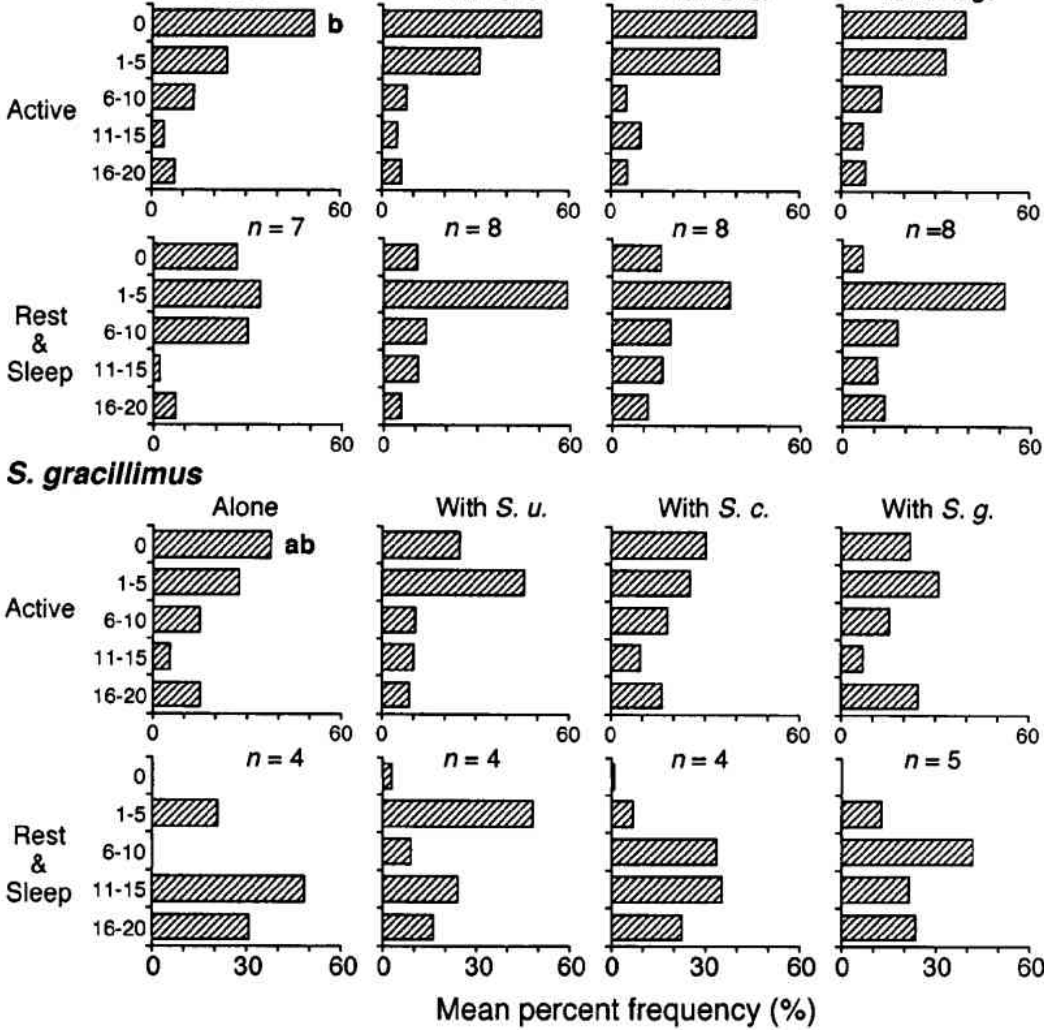

Fig. 3. Vertical spatial use of shrews when they were alone and with con-or hetero-specific individuals (mean percent frequency). The same bold letters $(a, b)$ indicate non-significant difference in mean percent frequency for the floor surface $(0)$ between species when shrews were "alone" ( $\alpha=0.05$, ANOVA, arcsine transformation, Scheffe's method; the sequential Bonferroni correction among levels, Rice 1989). There was significant difference neither among species for the other levels when alone nor among experimental treatments for each level within species. 
Table 1. The ratios of "active" and "rest \& sleep" phases in three shrew species observed in Experiment 1 (mean percent frequency $\pm S D$ ). Mean percentages in the "alone" column differed significantly between any two of the three species $(\alpha=0.05$, ANOVA, arcsine transformation, Scheffe's method). The different letters indicate significant differences. The mean percentages did not differ significantly among the experimntal treatments within species.

\begin{tabular}{ccccc}
\hline & & \multicolumn{3}{c}{ With } \\
\cline { 4 - 5 } $\begin{array}{c}\text { Experimental } \\
\text { treatment }\end{array}$ & Alone & S. $u$. & S. $c$. & S. $g$. \\
\hline $\begin{array}{c}\text { S. unguiculatus } \\
\text { Active }\end{array}$ & $\mathrm{a}$ & & & \\
Rest and Sleep & $33.0 \pm 10.9$ & $38.7 \pm 15.5$ & $39.2 \pm 12.8$ & $41.4 \pm 17.1$ \\
$(n)$ & 67.0 & 61.3 & 60.8 & 58.6 \\
S. caecutiens & $(8)$ & $(8)$ & $(8)$ & $(9)$ \\
Active & $\mathrm{b}$ & & & \\
Rest and Sleep & $70.6 \pm 12.1$ & $73.3 \pm 17.9$ & $65.5 \pm 25.0$ & $68.6 \pm 8.2$ \\
$(n)$ & 29.4 & 26.7 & 34.5 & 31.4 \\
S. gracillimus & $(7)$ & $(8)$ & $(8)$ & $(8)$ \\
Active & $\mathrm{c}$ & & & \\
Rest and Sleep & $50.0 \pm 10.4$ & $60.5 \pm 12.4$ & $50.8 \pm 6.2$ & $53.8 \pm 12.2$ \\
$(n)$ & 50.0 & 39.5 & 49.2 & 44.2 \\
& $(4)$ & $(4)$ & $(4)$ & $(5)$ \\
\hline
\end{tabular}

had no apparent effect on vertical space use ; there were no significant differences for almost all comparisons.

The percentages of active and non-active phases did not differ significantly between the exrimental treatments (alone and with con- or hetero-specific individuals) in any of the three species (ANOVA with arcsine transformation by Scheffe's method, $\alpha=0.05$, Table 1). Interspecific differences in activity when animals were "alone" were, however, significant. S. caecutiens was most active, S. unguiculatus was least active, and S. gracillimus was intermediate between them. Dominance relationships between two individuals (win, even, lose, or no match) also had no effect on activities of shrews.

\section{Experiment 2}

The use of "home" or "away" cage did not differ significantly among species when shrews were "alone" (ANOVA, $\alpha=0.05$ ). S. unguiculatus, however, tended to stay in its "home" cage more than either of the other two species (Table 2). The experimental treatments (alone and with con- or hetero-specific individuals) also had no effect on the use of "home" and "away" cages for any of the three species (Table 2). The dominance relationships tended not to influence the use of either the "home" or "away" cage in the three species; there were no significant differences for almost all comparisons.

When two individuals were introduced into two interconnected cages, they tended to stay in separate cages (Table 3). The mean percentage of time spent in a single cage or separate cages did not differ significantly among the experimental treatments. 
Table 2. The utilization of "home" and "away" cages by three shrew species observed in Experiment 2 (mean percent frequency $\pm S D$ ). The mean percentages differed significantly neither between the experimental treatments within species nor between species when shrews were "alone" ( $\alpha=0.05$, ANOVA, arcsine transformation, Scheffe's method).

\begin{tabular}{ccccc}
\hline & & \multicolumn{3}{c}{ With } \\
\cline { 3 - 5 } $\begin{array}{c}\text { Experimental } \\
\text { treatment }\end{array}$ & Alone & S. $u$. & $S . c$. & S. g. \\
\hline S. unguiculatus & & & & \\
Home & $70.7 \pm 28.3$ & $76.9 \pm 20.5$ & $64.2 \pm 36.5$ & $72.1 \pm 29.1$ \\
Away & 29.3 & 23.1 & 35.8 & 27.9 \\
$(n)$ & $(10)$ & $(10)$ & $(10)$ & $(10)$ \\
S. caecutiens & & & & \\
Home & $50.7 \pm 31.9$ & $52.0 \pm 26.6$ & $36.3 \pm 11.6$ & $49.6 \pm 23.2$ \\
Away & 49.3 & 48.0 & 63.7 & 50.4 \\
$(n)$ & $(4)$ & $(4)$ & $(4)$ & $(4)$ \\
S. gracillimus & & & & \\
Home & $56.5 \pm 29.7$ & $68.0 \pm 7.9$ & $48.2 \pm 29.4$ & $48.2 \pm 18.5$ \\
Away & 43.5 & 32.0 & 51.8 & 51.8 \\
$(n)$ & $(4)$ & $(4)$ & $(5)$ & $(4)$ \\
\hline
\end{tabular}

S. unguiculatus remained underground or dug soil significantly more fre quently $(\alpha=0.05)$ than did either $S$. caecutiens or S. gracillimus when they were in their "home" cages (Fig. 4). The mean frequencies of the three behavioral categories, however, did not differ significantly among the three species when they were in "away" cages (Fig. 4).

S. unguiculatus was "active underground" significantly more frequently in its "home" cage than it was in the "away" cage under each of the experimental

Table 3. Occupation of cages by two shrews in Experiment 2 (mean percent frequency $\pm S D$ of staying in the same cage and separate cages). The means did not differ significantly between any comparisons ( $\alpha=0.05$, ANOVA, arcsine transformation, Scheffe's method). $n$ : number of experimental sessions examined.

\begin{tabular}{cccc}
\hline & \multicolumn{3}{c}{ With } \\
\cline { 2 - 4 } & S. unguiculatus & S. caecutiens & S. gracillimus \\
\hline S. unguiculatus & & & \\
Same & $35.9 \pm 19.9$ & $35.6 \pm 17.3$ & $24.2 \pm 14.3$ \\
Different & 64.1 & 64.4 & 75.8 \\
$(n)$ & $(5)$ & $(10)$ & $(10)$ \\
S. caecutiens & & & \\
Same & - & $33.9 \pm 19.6$ & $38.4 \pm 15.0$ \\
Different & - & 66.1 & 66.3 \\
$(n)$ & & $(5)$ & $(9)$ \\
S. gracillimus & - & - & $54.8 \pm 10.7$ \\
Same & - & - & 45.2 \\
Different & & & $(4)$ \\
$(n)$ & & &
\end{tabular}




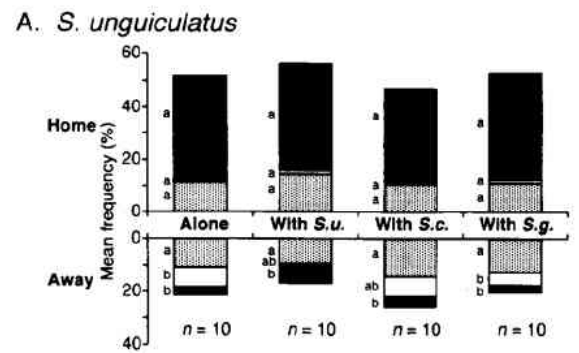

B. S. caecutiens

C. S. gracillimus
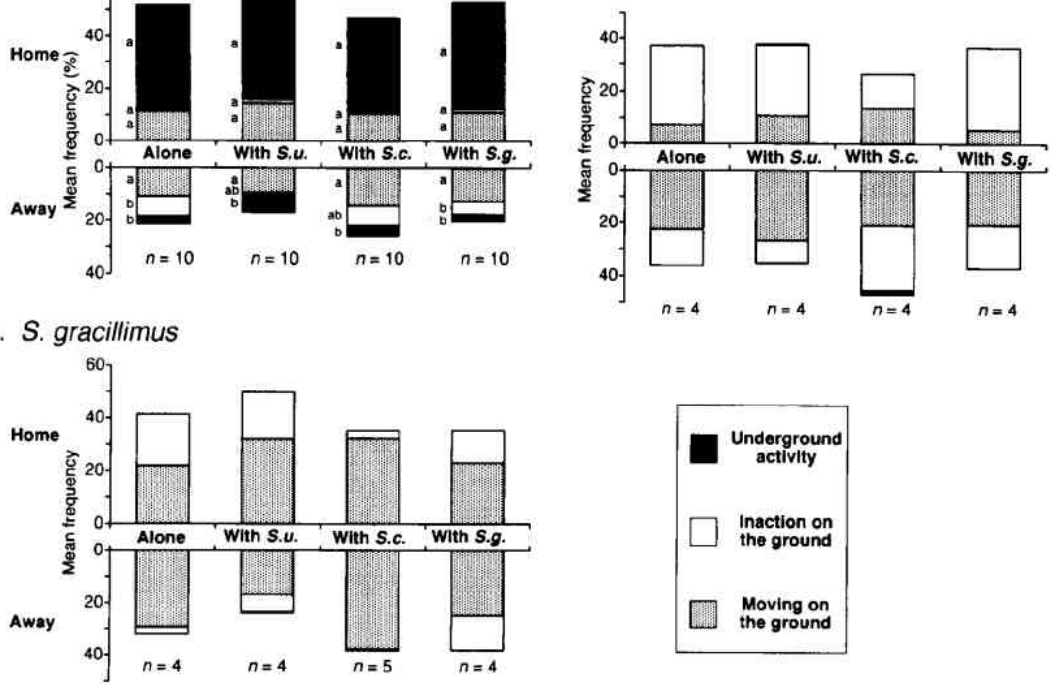

Fig. 4. The effects of con-or hetero-specific individuals on the behavior of shrews (mean percent frequency). The same letters indicate non-significant difference in mean frequency of each behavior category among the experimental treatments and between "home" and "away" cages within experimental treatment $(\alpha=0.05$, ANOVA, Scheffe's method). In $S$. caecutiens and S. gracillimus, any significant difference in behavioral category was not found among the experimental treatments nor between "home" and "away" cages.

treatments (Fig. 4-A). In contrast, the mean frequency of each behavior in $S$. caecutiens and S. gracillimus did not differ significantly between the "home" and "away" cage situations (Fig. 4-B, C). The experimental treatments (alone and with con- or hetero-specific individuals) also had no effect on the behavioral patterns for any of the three species (Fig. 4).

The relationship between the mean frequencies of the behavioral categ. ories and the dominance relation was not fully analyzed because of small sample size. However, behavioral patterns appeared not to be affected by the dominance relationship.

\section{Dominance relationships and attacks}

Among the three species, S. unguiculatus was most dominant and S. gracillimus was most submissive in terms of physical superiority. S. unguiculatus was seldom defeated by $S$. caecutiens and never defeated by S. gracillimus (Table 4). Furthermore, "no match" was the major result between conspecific individuals of S. unguiculatus in Experiment 2, but this result might be an artifact of the observation method that underground behaviors could not be observed. S. caecutiens beat $S$. gracillimus in most combats.

S. unguiculatus showed no significant difference in the number of attacks 
Table 4. Dominance relations between two con- or hetero-specific individuals in Experiments 1 and 2 (numbers of individuals of four kinds of the relation). Results of different experimental sessions for an individual were treated as diffrent counts.

\begin{tabular}{lllll}
\hline & & \multicolumn{3}{c}{ Opponent } \\
\cline { 3 - 5 } & & $S . u$. & $S . c$. & $S . g$. \\
\hline Experiment 1 & win & 4 & 6 & 6 \\
S. unguiculatus & even & 4 & 4 & 1 \\
& lose & 4 & 0 & 0 \\
& no match & 0 & 2 & 3 \\
S. caecutiens & win & 0 & 5 & 4 \\
& even & 4 & 4 & 2 \\
& lose & 6 & 5 & 1 \\
S. gracillimus & no match & 2 & 0 & 2 \\
& win & 0 & 1 & 2 \\
& even & 1 & 2 & 4 \\
Experiment 2 & lose & 6 & 4 & 2 \\
S. unguiculatus & no match & 3 & 2 & 0 \\
& & & & \\
& win & 1 & 6 & 8 \\
S. caecutiens & even & 0 & 1 & 0 \\
& lose & 1 & 1 & 0 \\
& no match & 8 & 2 & 2 \\
& win & 1 & 5 & 7 \\
S. gracillimus & even & 1 & 0 & 0 \\
& lose & 6 & 5 & 0 \\
& no match & 2 & 0 & 2 \\
& win & 0 & 0 & 4 \\
& even & 0 & 0 & 0 \\
& lose & 8 & 7 & 4 \\
& no match & 2 & 2 & 0 \\
\hline
\end{tabular}

Table 5. Mean numbers of attacks $( \pm S D)$ between two individuals in Experiment 2. The same letters indicate non-significant difference $(\alpha=$ 0.05, Mann-Whitney's $U$-test, the sequential Bonnferroni correction, Rice 1989). The first letters before comma indicate the results of betweencolumm comparisons and the second letters are those of between-rows. Numbers parentheses are those of observations examined.

\begin{tabular}{lccc}
\hline & \multicolumn{3}{c}{ Against } \\
\cline { 2 - 4 } S. unguiculatus & S. $u$. & S.. & S. $g$. \\
\cline { 2 - 4 } & $\begin{array}{c}0.5 \pm 0.7 \\
(2) \mathrm{a}, \mathrm{a}\end{array}$ & $\begin{array}{c}1.2 \pm 1.6 \\
(8) \mathrm{a}, \mathrm{a}\end{array}$ & $\begin{array}{c}5.6 \pm 9.3 \\
(8) \mathrm{a}, \mathrm{a}\end{array}$ \\
S. caecutiens & $\begin{array}{c}1.0 \pm 1.4 \\
(8) \mathrm{a}, \mathrm{a}\end{array}$ & $\begin{array}{c}6.4 \pm 8.9 \\
(10) \mathrm{a}, \mathrm{a}\end{array}$ & $\begin{array}{c}27.4 \pm 16.6 \\
(7) \mathrm{b}, \mathrm{b}\end{array}$ \\
S. gracillimus & $\begin{array}{c}0 \pm 0.0 \\
(8) \mathrm{a}, \mathrm{a}\end{array}$ & $\begin{array}{c}0.6 \pm 0.5 \\
(7) \mathrm{b}, \mathrm{a}\end{array}$ & $\begin{array}{c}0.9 \pm 1.4 \\
(8) \mathrm{ab}, \mathrm{a}\end{array}$ \\
\hline
\end{tabular}


against other individuals (Table 5). S. caecutiens attacked S. gracillimus significantly more frequently than it did $S$. unguiculatus or other S. caecutiens. $S$. gracillimus attacked other individuals less frequently than did either of the other two species. S. gracillimus was attacked more often by S. caecutiens than by $S$. unguiculatus or by conspecifics (Table 5)

\section{Discussion}

S. unguiculatus was frequently active underground, whereas $S$. caecutiens mainly used the ground surface (Figs. 3 and 4). S. gracillimus showed an intermediate vertical use of space in Experiment 1, but it was primarily a ground-surface dweller (Fig. 4) in Experiment 2, which was deemed to simulate natural conditions more realistically than Experiment 1.

The interspecific differences in use of space were consistent with those in burrowing habits (Ohdachi 1995c) and in dietary constituents (Abe 1968, Inoue and Maekawa 1990, Ohdachi 1995b): S. caecutiens and S. gracillimus, which are poor burrowers and mainly eat small epigeal arthropods, showed more surface activity than did $S$. unguiculatus, which was a superior burrower and a heavy consumer of earthworms.

The presence of a con- or hetero-specific individual or their dominance relationships affected neither the space utilization nor the mean frequencies of behaviors (active/inactive and underground/resting/ground surface activity) in each of the three shrew species. S. unguiculatus was intrinsically different in its use of space (especially vertically) from $S$. caecutiens and S. gracillimus. It is, therefore, likely that direct interaction or interference over space is less frequent between S. unguiculatus and either of S. caecutiens or S. gracillimus than between the latter two species.

A dominance order among the three species was evident (Table 4) and seemed to correspond with the shrews' body size. The strongest S. un guiculatus weighs on average approximately twice as much as the secondranked $S$. caecutiens, and $S$. caecutiens is 1.5 times as heavy as the weakest $S$. gracillimus (Ohdachi and Maekawa 1990b). The correlation between fighting ability and body size has also been reported from some other insectivorous or carnivorous vertebrates (e.g., Persson 1985, Alatalo and Moreno 1987, Dickman 1988, Erlinge and Sandell 1988, Ducey et al.1994, Nakano and FurukawaTanaka 1994).

Each of the three shrew species exhibited antagonistic behavior whenever two con- or hetero-specific individuals encountered, although S. gracillimus were least likely to attack. It may have been this tendency that led them to remain in whichever cage was not occupied by its opponent (Table 3). Many other soricine species also show antagonism against con- or hetero-specific individuals (Crowcroft 1957, Olsen 1969, Hawes 1977, Martin 1981, Barnard and Brown 1982, Churchfield 1990, Ellenbroek 1990, Dickman 1991, Ellenbroek and Hamburger 1991, Krushinska and Rychlik 1993). However, some species, such as Neomys anomalus and Cryptotis parva, are tolerant towards conspecifics 
(Broadbooks 1952, Conaway 1958, Mock 1982, Krushinska and Pucek 1989, Krushinska and Rychlik 1993). Krushinska and Pucek (1989) reported that acquaintance reactions, such as warning and nasal contact, were observed in $N$. anomalus when two individuals met. In their study, shrews gradually avoided direct conflict by learning their place of the dominance rank. In the present study, such acquaintance behaviors were not observed; shrews suddenly attacked other individuals (or were attacked) throughout experiments. The lack of acquaintance behavior in the present study might have resulted from the brevity of experiments which might have led to their intolerance of other individuals.

Although S. unguiculatus was strongest of the three species (Table 4), it attacked other two species less frequently (Table 5). In the present study, attacks could only be observed among animals on the ground surface, which might thus underestimate the attacking frequency of $S$. unguiculatus. Under natural conditions, however, attacks by $S$. unguiculatus against $S$. caecutiens and S. gracillimus are also probably rare, because the latter two species use subterranean space less frequently and presumably rarely encounter S. unguiculatus.

Soricids usually establish intraspecific territories or exclusive home ranges, especially among individuals of the same sex (Ingles 1961, Shillito 1963, Buckner 1966, 1969, Croin-Michielsen 1966, Platt 1976, Hawes 1977, Pernetta 1977, Inoue 1988, 1991, Ohdachi 1992, Ivanter et al. 1994, Moraleva and Telitzina 1994, Stockley et al. 1994). Such territoriality seems to be maintained by aggressive behavior and odor marking (Crowcroft 1957, Hawes 1976). Two types of interspecific spatial relationships are known among soricine shrews. In the first type, territories overlap between species, as between $S$. araneus and S. minutus (Croin-Michielsen 1966, Pernetta 1977, Ellenbroek 1980). In the second type, there is interspecific territoriality as between $S$. cinereus and $S$. vagrans (Spencer and Pettus 1966) and between S. vagrans and S. obscurus (Hawes 1977). In Hokkaido, S. unguiculatus and either of S. gracillimus or S. caecutiens appear to have overlapped territories (Ohdachi 1992). The occurrence of overlapped territories might be explained by the interspecific difference in vertical space use: S. unguiculatus appears only rarely to encounter either S. gracillimus or S. caecutiens in the field. In contrast, inferring from the results of the present study (Figs. 3 and 4), it is plausible that $S$. caecutiens and S. gracillimus maintain interspecific territories when in symtopy, because both species are ground-surface dwellers and they do not shift their space of activity even when they co-habituate.

$S$. caecutiens tenaciously attacks $S$. gracillimus, and the latter seldom beats $S$. caecutiens. The similarity in space use and the physical inferiority of $S$. gracillimus could lead to its exclusion from habitats where $S$. caecutiens occurs. Moreover, recipients of aggressive behavior may experience reduced fitness in general (King 1973). This could partly explain the relative abundances of the two species in a given habitat (Ohdachi and Maekawa 1990a): S. caecutiens and $S$. gracillimus do not occur together as the first and second most abundant 
species. However, if $S$. caecutiens were to always exclude S. gracillimus, then $S$. gracillimus would be unable to occur in Hokkaido. In reality, S. gracillimus outnumbers $S$. caecutiens and $S$. unguiculatus in some habitats (Ohdachi and Maekawa 1990a). This might be attributed to interspecific differences in habitat preference. S. gracillimus is the most abundant species in moor and uplands, especially, in northern Hokkaido, whereas S. caecutiens tends to outnumber other species in habitats with sandy- or volcanic ash-soils (Ohdachi and Maekawa 1990a), which implies that each species prefers particular environments. Furthermore, competitive (interference) capabilities may vary in relation to such environmental variables as temperature, humidity, or soil type, and the result of competition depends on environmental conditions. Such phenomena are known in fish (Dunson and Travis 1991, De Staso and Rahel 1994), planktons (Hessen et al. 1995), and beetles (Park 1954). Also, the distribution pattern of soricids in Hokkaido is probably determined by a combination of both competitive ability and environmental conditions. In order to understand community organization or distribution pattern of the shrews in Hokkaido, further investigations of the effect of environmental conditions on competitive ability are recommended.

Acknowledgments : I would like to express my deep gratitude to: H. Abe, M. J. Toda, S. F. Mawatari, T. Ohgushi, and T. P. Craig for reviewing earlier drafts of this paper, K. Ishigaki, K. Sasa, and other staff members of the Experimental Forests of Hokkaido University for supporting the field work, T. Segawa, S. Nakatsubo, and H. Ishii for making the equipment for the experiments, students of the Institute of Low Temperature Science and the Laboratory of Applied Zoology, Hokkaido University, who provided assistance with laboratory experiments, and also S. Nakano, who referred me to some important research papers.

\section{REFERENCES}

Abe, H. 1968. Classification and biology of Japanese Insectivora (Mammalia) II. Biological aspects. J. Fac. Agr., Hokkaido Univ. 55 : 429-458.

Alatalo, R. V. and J. Moreno. 1987. Body size, interspecific interactions, and use of foraging sites in tits (Paridae). Ecology $65: 1773-1777$.

Arthur, W. 1987. The Niche in Competition and Evolution. John Wiely and Sons, Chichester, 175 pp.

Barnard, C. J. and C. A. J. Brown. 1982. The effects of prior residence, competitive ability and food availability on the outcome of interactions between shrews (Sorex araneus L.). Behav. Ecol. and Sociobiol. $10: 307-312$.

Bennett, W. A. 1990. Scale of investigation and the detection of competition: an example from the house sparrow and house finch introductions in North America. Am. Nat. 135: 725-747.

Broadbooks, H. E. 1952. Nest and behavior of a short-tailed shrew, Cryptotis parva. J. Mammal. 33 : 241-243.

Buckner, C. H. 1966. Populations and ecological relations of shrews in tamarack bogs of southeastern Manitoba. J. Mammal. $47: 181-194$.

Buckner, C. H. 1969. Some aspects of the population ecology of the common shrew, Sorex araneus, 
near Oxford, England. J. Mammal. $50: 326-332$.

Churchfield, S. 1990. The Natural History of Shrews. A \& C Black., London, 178 pp.

Conaway, C. H. 1958. Maintenance, reproduction and growth of the least shrew in captivity. J. Mammal. $39: 507-512$.

Croin-Michielsen, N. 1966. Intraspecific and interspecific competition in the shrews Sorex araneus L. and S. minutus L. Arch. Néerland. Zool. 18:73-174.

Crowcroft, P. 1957. The Life of the Shrew. Max Reinhardt, London, 166 pp.

De Staso, J., III, and F. J. Rahel. 1994. Influence of water temperature on competitive interactions between juvenile brook trout and Colorado river cutthroat trout in a laboratory stream. Trans. Am. Fish. Soc. $123: 289-297$.

Diamond, J. M. 1986. Overview: laboratory experiments, field experiments, and natural experiments. In (J. M. Diamond and T. J. Case, eds.) Community Ecology. pp. 3-22. Harper \& Row, New York.

Dickman, C. R. 1988. Body size, prey size, and community structure in insectivorous mammals. Ecology $69: 569-580$.

Dickman, C. R. 1991. Mechanisms of competition among insectivorous mammals. Oecologia 85 : $464-471$.

Ducey, P. K., K. Schramm and N. Cambry. 1994. Interspecific aggression between the sympatric salamanders, Ambystoma maculatum and Plethodon cinereus. Amer. Midl. Natur. $131: 320-$ 329.

Dunson, W. A. and J. Travis. 1991. The role of abiotic factors in community organization. Am. Nat. $138: 1067-1091$.

Ellenbroek, F. J. M. 1980. Interspecific competition in the shrews Sorex araneus and Sorex minutus (Soricidae, Insectivora) : a population study of the Irish pygmy shrew. J. Zool., London 192: $119-136$.

Ellenbroek, F. J. M. 1990. An Experimental Analysis of Interspecific Competition in the Shrews Sorex araneus L. and S. minutus L. (Soricidae, Insectivora). H. Gianotten, Tilburg, $125 \mathrm{pp}$.

Ellenbroek, F. J. M. and J. Hamburger. 1991. Interspecific interactions between the shrews Sorex araneus L. and S. minutus L. (Soricidae, Insectivora) and the use of habitat: a laboratory study. Netherl. J. Zool. $41: 32-62$.

Erlinge, S. and M. Sandell. 1988. Coexistence of stoat, Mustela erminea, and weasel, M. nivalis : social dominance, scent communication, and reciprocal distribution. Oikos $53: 242-246$.

Hardin, G. 1960. The competitive exclusion principle. Science 131:1292-1297.

Hairston, N.G., Sr. 1989. Ecological Experiments. Purpose, Design, and Execution. Cambridge University Press, Cambridge, 370 pp.

Hawes, M. L. 1976. Odor as a possible isolating mechanism in sympatric species of shrews (Sorex vagrans and Sorex obscurus). J. Mammal. $57: 404-406$.

Hawes, M. L. 1977. Home range, territoriality, and ecological separation in sympatric shrews, Sorex vagrans and Sorex obscurus. J. Mammal. $58: 354-367$.

Hessen, D. O., B. A. Faafeng and T. Anderson. 1995. Competition or niche segregation between Holopedium and Daphnia: empirical light on abiotic key parameters. Hydrobiol. $307: 253-$ 261.

Holbrook, S. J. 1979. Habitat utilization, competitive interactions, and coexistence of three species of cicetine rodents in east-central Arizona. Ecology $60: 758-769$.

Ingles, L. G. 1961. Home range and habitats of the wandering shrew. J. Mammal. 42:455-462.

Inoue, T. 1988. Territory establishment of young big-clawed shrew, Sorex unguiculatus (Dobson) (Insectivora, Soricidae). Res. Popul. Ecol. $30: 83-93$.

Inoue, T. 1991. Sex difference in spatial distribution of the big-clawed shrew Sorex unguiculatus. Acta Theriol. $36: 229-237$.

Inoue, T. and K. Maekawa. 1990. Difference in diets between two species of soricine shrews, Sorex unguiculatus and $S$. caecutiens. Acta Theriol. $35: 253-260$.

Ivanter, E. V., T. Ivanter and A. M. Makarow. 1994. The territorial and demographic structures of a common shrews population. In (J. F. Merritt, G. L. Kirkland Jr. and R. K. Rose, eds.) Advances in the Biology of Shrews. pp. 89-96. Carnegie Museum of Natural History, 
Pittsburgh.

Keddy, P. A. 1989. Competition. Chapman and Hall, London, 202 pp.

King, J. A. 1973. The ecology of aggressive behavior. Ann. Rev. Ecol. Syst. 4:117-138.

Krushinska, N. L. and Z. Pucek. 1989. Ethological study of sympatric species of European water shrews. Acta Theriol. $34: 269-285$.

Krushinska, N. L. and L. Rychlik. 1993. Intra- and interspecific antagonistic behaviour in two sympatric species of water shrews: Neomys fodiens and N. anomalus. J. Ethol. 11:11-21.

Martin, I. G. 1981. Tolerance of conspecifics by short-tailed shrews (Blarina brevicauda) in simulated natural conditions. Am. Midl. Nat. 106: 206-208.

Mock, O. B. 1982. The least shrew (Cryptotis parva) as a laboratory animal. Lab. Anim. Sci. 32 : 177-179.

Moraleva, N. and A. Telitzina. 1994. Territoriality in juveniles of the common shrew (Sorex araneus) in prepeak and peak years of population. In (J. F. Merritt, G. L. Kirkland Jr. and R. K. Rose, eds.) Advances in the Biology of Shrews. pp. 67-76. Carnegie Museum of Natural History, Pittsburgh.

Nakano, S. and T. Furukawa-Tanaka. 1994. Intra- and interspecific dominance hierarchies and variation in foraging tactics of two species of stream-dwelling chars. Ecol. Res. 9:9-20.

Ohdachi, S. 1992. Home ranges of sympatric soricine shrews in Hokkaido, Japan. Acta Theriol. $37: 91-101$.

Ohdachi, S. 1994. Total activity rhythms of three soricine species in Hokkaido. J. Mamm. Soc. Japan 19:89-99.

Ohdachi, S. 1995a. Comparative Ecology and Ethology of Sympatric Soricine Shrews in Hokkaido: A Special Reference to Their Interspecific Interactions. Ph. D. Dissertation at the Graduate School of Science, Hokkaido University, $116 \mathrm{pp}$.

Ohdachi, S. 1995b. Diets and abundances of three sympatric shrew species in northern Hokkaido. J. Mammal. Soc. Japan $20: 69-83$.

Ohdachi, S. 1995c. Burrowing habits and earthworm preference of three species of Sorex in Hokkaido. J. Mammal. Soc. Japan 20:85-88.

Ohdachi, S. and K. Maekawa. 1990a. Geographic distribution and relative abundance of four species of soricine shrews in Hokkaido, Japan. Acta Theriol. 35:261-267.

Ohdachi, S. and K. Maekawa. 1990b. Relative age, body weight, and reproductive condition in three species of Sorex (Soricidae; Mammalia) in Hokkaido. Res. Bull. Coll. Exp. For., Fac. Agr., Hokkaido Univ. $47: 535-546$.

Olsen, R. W. 1969. Agonistic behavior of the short-tailed shrew (Blarina brevicauda). J. Mammal. $50: 494-500$.

Park, T. 1954. Experimental studies of interspecies competition. II. Temperature, humidity, and competition in two species of Tribolium. Physiol. Zool. 27:177-229.

Parker, G. A. and W. J. Sutherland. 1986. Ideal free distributions when individuals differ in competitive ability: phenotype-limited ideal free models. Anim. Behav. 34 : 1222-1242.

Pernetta, J. C. 1977. Population ecology of British shrews in grassland. Acta Theriol. 22:279-296.

Persson, L. 1985. Asymmetrical competition : are larger animals competitively superior? Am. Nat. $126: 261-266$.

Platt, W. J. 1976. The social organization and territoriality of short-tailed shrew (Blarina brevicauda) population in old-field habitats. Anim. Behav. $24: 305-318$.

Rice, W. R. 1989. Analyzing tables of statistical tests. Evolution $43: 223-225$.

Schoener, T.W. 1975. Presence and absence of habitat shift in some widespread lizard species. Ecol. Monogr. 45 : 233-259.

Shillito (Babington), J. F. 1963. Observations on the range and movements of a woodland population of the common shrew Sorex araneus L. Proc. Zool. Soc., London $140: 533-546$.

Spencer, A. W. and D. Pettus. 1966. Habitat preference of five species of long-tailed shrews. Ecology $47: 677-683$.

Stockley, P., J. B. Searle, D. W. Macdonald and C. S. Jones. 1994. Alternative reproductive tactics in male common shrews: relationships between mate-searching behaviour, sperm production, and reproductive success as revealed by DNA fingerprinting. Behav. Ecol. Sociobiol. 34 : 
$71-78$.

Werner, E. E. and D. J. Hall. 1976. Niche shifts in sunfishes: experimental evidence and significance. Science $191: 404-406$.

(accepted 26 July 1997) 